Proc. Estonian Acad. Sci. Biol. Ecol., 2005, 54, 4, 271-278

\title{
Achaeta unibulba sp. n., a widespread European species (Oligochaeta, Enchytraeidae)
}

\author{
Ulfert Graefe $^{\mathrm{a}^{*}}$, Klára Dózsa-Farkas ${ }^{\mathrm{b}}$, and Bent Christensen ${ }^{\mathrm{c}}$ \\ ${ }^{a}$ Institute for Applied Soil Biology GmbH, Sodenkamp 62, 22337 Hamburg, Germany \\ ${ }^{\mathrm{b}}$ Department of Systematic Zoology and Ecology, Eötvös Loránd University, Pázmány Péter sétány \\ 1/C, H-1117 Budapest, Hungary; dfk01@cerberus.elte.hu \\ c Department of Evolutionary Biology, Biological Institute, Universitetsparken 15, 2100 Copenhagen, \\ Denmark; BChristensen@bi.ku.dk
}

Received 12 October 2004, in revised form 5 April 2005

\begin{abstract}
Achaeta unibulba sp. n. is described from a variety of terrestrial habitats in Europe. The new species is similar to a group of species around A. eiseni Vejdovský, 1878, having bottle-shaped glands (= setal follicles) dorsally and ventrally, the latter being only slightly smaller. Its main distinguishing characters are the fused penial bulbs forming a large roundish body at the ventral midline, the absence of accessory penial glands, the arrangement of clitellum glands, the presence of a large gland at the orifice of the spermathecae, an oesophageal appendage in $\mathrm{V}$ without canal leading to pharynx, and the presence of three pairs of preclitellar nephridia. The species occurs in slightly acid to neutral soils. It was found in mineral horizons of mull humus forms as well as in fen peat.
\end{abstract}

Key words: Oligochaeta, Enchytraeidae, Achaeta, new species, Europe.

\section{INTRODUCTION}

This species was first found and recognized as new species in the 1970s and then observed at numerous soil monitoring sites (BDF: Bodendauerbeobachtungsfläche) in Germany. Later it was recorded also from Iceland, Denmark, and Hungary and finally found in Estonia in 2004 by participants of the 6th International Symposium on Enchytraeidae (Schmelz et al. 2005). It thus appears

* Corresponding author, ulfert.graefe@ifab-hamburg.de 
to be a widespread species in Europe. The intention of the present paper is to describe this well-known species and to give it a valid name. A revision of the most related species will be published elsewhere.

\section{MATERIAL AND METHODS}

Living and preserved specimens were examined with interference contrast light microscopy (Leitz Dialux). Specimens were fixed hot $\left(70^{\circ} \mathrm{C}\right)$ either in Bouin's fluid or in sublimat-formol-acetic acid after Broch from Reisinger (1925), or they were preserved in $70 \%$ ethanol. They were stained with borax-carmine and mounted in Canada balsam or euparal. Some preserved specimens were held in clove oil and were documented photographically and as drawings with the help of a drawing tube. Living animals were recorded on videotape (Zeiss Axioscope 2 microscope).

\section{Achaeta unibulba sp. n. (Figs. 1-4)}

Achaeta unibulba sp. n. but not published in Graefe (1973: Figs. 22-26.)

Achaeta unibulba nomen nudum: Mellin (1988), Schulte et al. (1989), Graefe (1993), Fründ \& Graefe (1994), Graefe (1998), Graefe et al. (1998), Beylich \& Graefe (2002)

The German type material including the holotype is deposited at the Zoological Museum of Hamburg, the other type material is deposited in the author's (K. Dózsa-Farkas) collection at the Department of Systematic Zoology and Ecology, Eötvös Loránd University, Budapest.

Holotype: ZMH OL 13193, stained whole mount.

Type locality: Germany, Schleswig-Holstein, Sachsenwald near Aumühle, damp forest soil, mull, coll. U. Graefe, V 1973.

Paratypes: Germany: ZMH OL 13194a-c, 3 spms, stained whole mounts, from different localities in Schleswig-Holstein: type locality; BDF 14 Meggerdorf, pasture, fen peat, coll. U. Graefe, XI 1994; BDF 25 Kudensee, pasture, fen peat, coll. U. Graefe, VII 1995.

Iceland: P.78.1 (1931) Vestur, grassland, $64^{\circ} 35^{\prime} \mathrm{N}, 21^{\circ} 36^{\prime} \mathrm{W}$, coll. T. Christensen, 1999, 3 spms.

Denmark: P.78.2 (1932) Langstrup Mose, North Zealand, coll. B. Christensen and K. Dózsa-Farkas, XI 1999, 1 spm; P.78.3 (1933) Ringelmosen, Kalø, forest, coll. B. Christensen and K. Dózsa-Farkas, VI 2000, 1 spm.

Hungary: P.78.4 (1934) Bükk Mountains, Omassa, Fagus-forest, 48 06'55" N, 20³3'20" E, 410 m, coll. K. Dózsa-Farkas, X 2003, 1 spm; P.78.5 (1935) Zemplén 

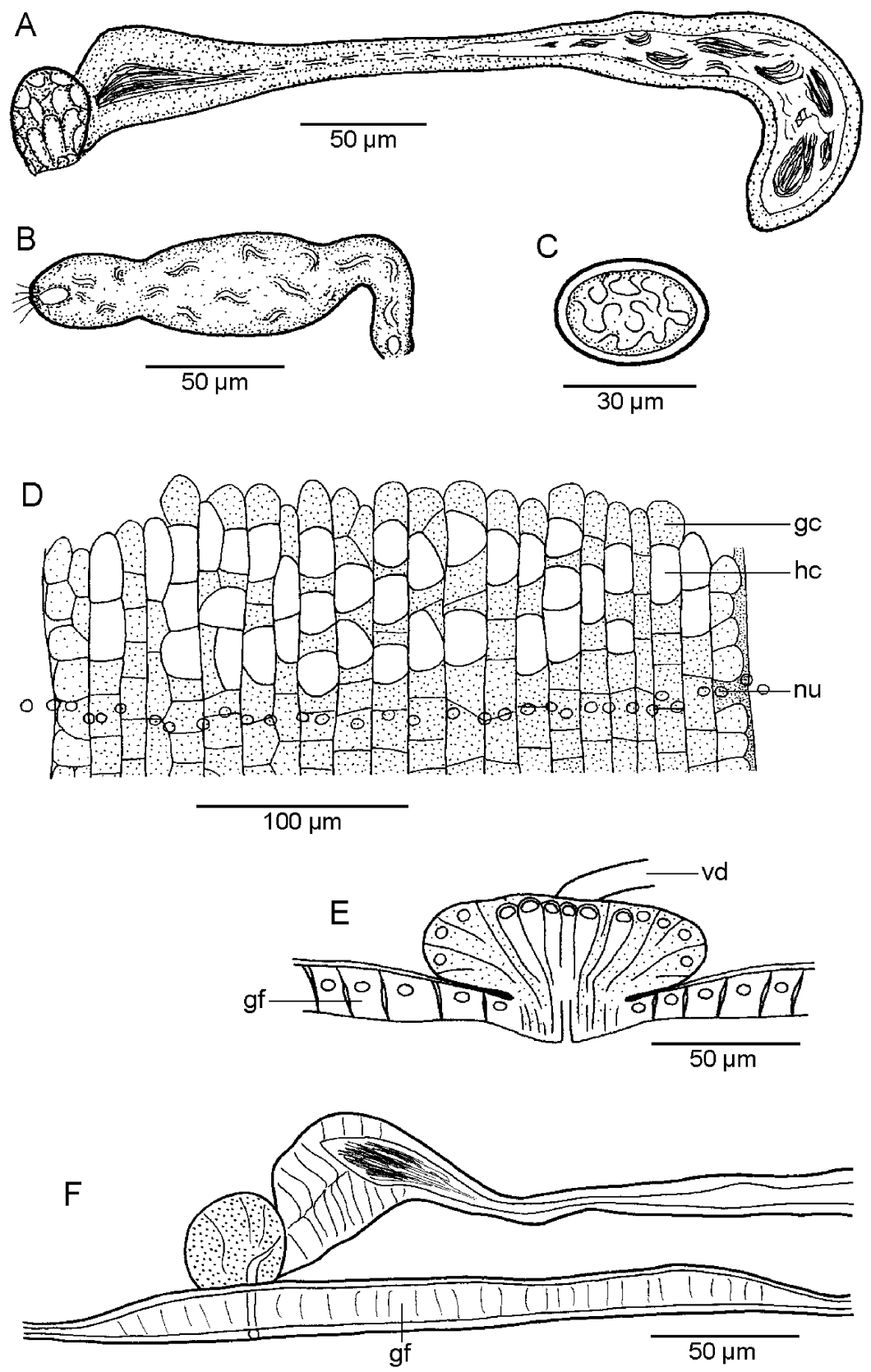

Fig. 1. Achaeta unibulba sp. n. A. Spermatheca. B. Preclitellar nephridium. C. Coelomocyte. D. Clitellum, dorsolateral view. E. Penial bulb, lateral view. F. Ectal part of spermatheca with seminal chamber, ectal gland, and glandular field of high epidermal cells, lateral view. A-C are freehand drawings; D-F are made from stained whole mounts with the help of a drawing tube. gc, granular cells of clitellum; gf, glandular field of high epidermal cells; hc, hyaline cells of clitellum; nu, nuclei of ring muscles forming together the lateral line; vd, vas deferens. 


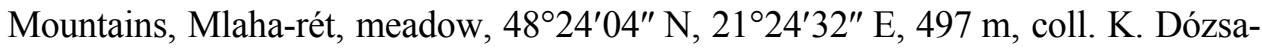
Farkas, V 2003, 2 spms; P.78.6 (1936) Zemplén Mountains, Mlaha-rét, birch-

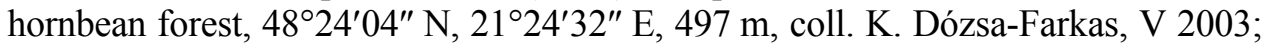
P.78.7 (1937) Zemplén Mountains, Mlaha-rét, birch-hornbean forest, 48 $24^{\prime} 04^{\prime \prime} \mathrm{N}$, $21^{\circ} 24^{\prime} 32^{\prime \prime}$ E, 497 m, coll. K. Dózsa-Farkas, V 2003, stained whole mount.

Etymology: The species name refers to the fused penial bulbs.

\section{RESULTS}

\section{Description}

Length $8-10 \mathrm{~mm}$ (viv.), diameter $0.2-0.3 \mathrm{~mm}$. Segment number $32-40$. Bottle-shaped glands (= setal follicles) present dorsally from II, ventrally from III. Length of dorsal glands $1 / 3$ to $1 / 2$ of body diameter, ventral glands slightly smaller. Lens-shaped epidermal glands present only laterally, not conspicuous. Brain two times as long as wide, rounded posteriorly. Three pairs of pharyngeal glands (= septal glands), all united dorsally and with ventral lobes (Fig. 2). Postseptal (= secondary) pharyngeal glands absent. Oesophageal appendage small, present only in $\mathrm{V}$, without mid-dorsal canal to pharynx. Three pairs of preclitellar nephridia (Fig. 1B) from 6/7 to 8/9, with large anteseptale and slight constriction at septum. Coelomocytes (Fig. 1C) 30-50 $\mu \mathrm{m}$ long, oval or tapering at one side, with small hyaline border and few inner grooves. Dorsal blood vessel originating

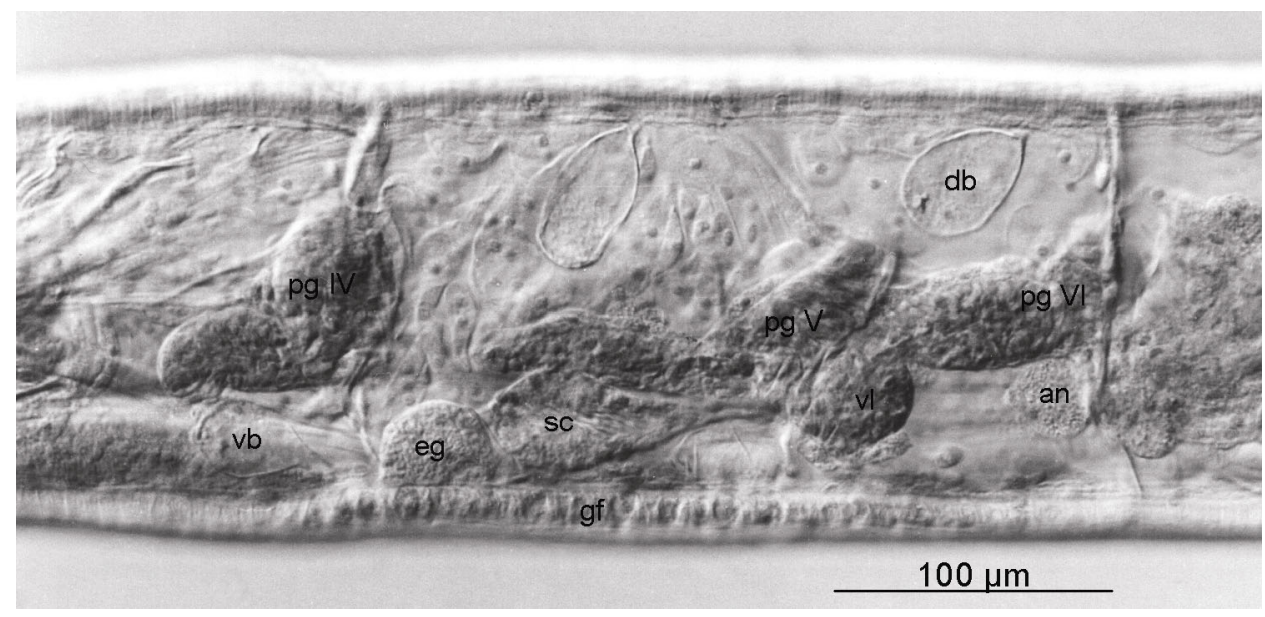

Fig. 2. Achaeta unibulba sp. n. Segments IV-VII, lateral view. Photograph from a stained specimen held in clove oil. an, anteseptale of nephridium at $6 / 7 ; \mathrm{db}$, dorsal bottle-shaped gland in VI; eg, ectal gland of spermatheca; gf, glandular field of high epidermal cells; pg, pharyngeal gland of segment IV, V, VI, respectively; sc, seminal chamber of spermatheca; vb, ventral bottle-shaped gland in IV; $\mathrm{vl}$, ventral lobe of pharyngeal gland in VI. 
in VII, with pulsating expansions in VII, VI, and V. Blood colourless. Clitellum (Fig. 1D) on XII- $-1 / 3$ XIII, dorsally with $60-70 \mu \mathrm{m}$ wide interruption. Glandular cells arranged in 20-23 transverse rows, but not in longitudinal rows. Dorso-lateral hyaline cells irregularly scattered. Glandular area bounded dorsolaterally by granular cells only. Testis in XI, ovary in XII, both unpaired at ventral midline. Seminal vesicle variable in size or poorly developed. Sperm funnel (Fig. 3) large cylindrical (length $220-300 \mu \mathrm{m}$ ), 4-6 times as long as wide, about 1.5 times as long as body diameter. Collar as wide as funnel body, separated from funnel body by a short neck-like constriction. Vas deferens very long, ca. $10 \mu \mathrm{m}$ wide, often coiled into a spiral. Male pores in XII, close to each other (ca. $25 \mu \mathrm{m}$ apart) near ventral midline, surrounded by glands extending into the body cavity, forming a compact mushroom-like penial bulb (Fig. 1E). Both penial bulbs fused to a conspicious roundish body at the ventral midline (Fig. 4). Accessory penial glands absent. A glandular field of high epidermal cells present before and behind male pores, filling the ventral gap of clitellum glands. Spermatheca (Figs. 1A, 1F) long, extending to XIII or IX. Ectal openings ventrally at 4/5, surrounded by a glandular field of high epidermal cells reaching backwards to 6/7. Ectal part of spermatheca consisting of seminal chamber and a large round multicellular gland in front of the ectal duct. Seminal chamber with thickened glandular walls and spindle-shaped lumen containing close-packed sperms, arranged almost perpendicular to the ectal duct. Entally the spermathecal duct is narrowing, expanding in VIII into a large thin-walled ampulla filled with sperm.

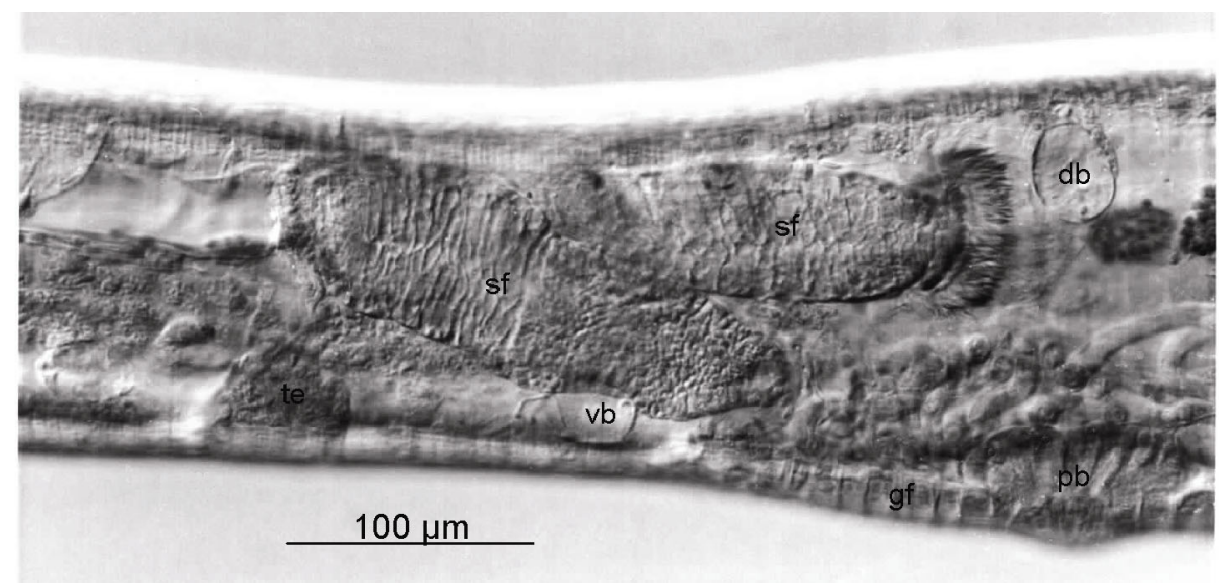

Fig. 3. Achaeta unibulba sp. n. Segments X-XII, lateral view. Photograph from a stained specimen held in clove oil. db, dorsal bottle-shaped gland in XII; gf, glandular field of high epidermal cells in the clitellar region; pb, penial bulb; sf, both sperm funnels; te, testis; vb, ventral bottle-shaped gland in XI. 


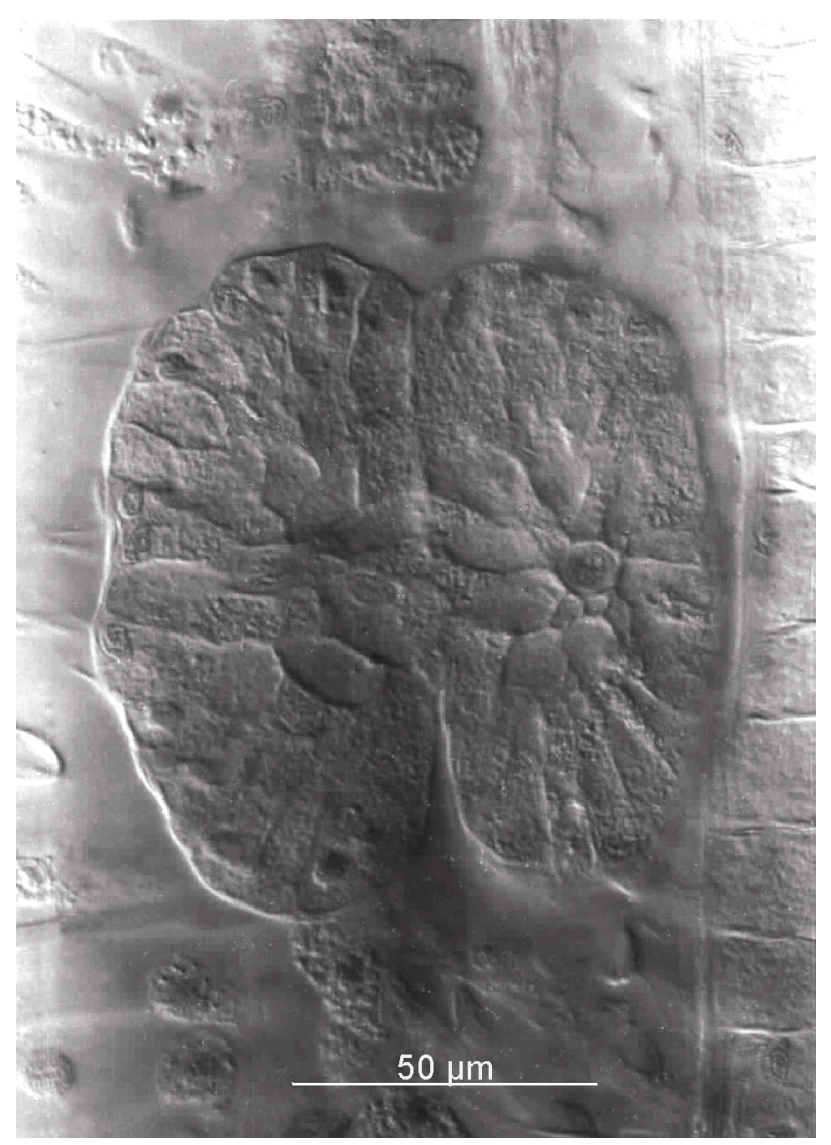

Fig. 4. Achaeta unibulba sp. n. The fused penial bulbs in XII, ventral view. Photograph from a stained specimen held in clove oil. All photographs made by U. Graefe using an interference contrast microscope.

\section{Remarks}

The first description of the new species in Graefe (1973) was performed as part of an initially planned comprehensive revision of the genus Achaeta Vejdovský, 1878. The finishing of this work unfortunately had to be postponed, owing to other obligations of the first author. At present the genus Achaeta comprises 40 nominal taxa. A comparison of related taxa is severely hampered by the lack of details in most of the older descriptions. One of the few features reported for all species is the absence or presence and arrangement of bottle-shaped epidermal glands, previously termed setal follicles (cf. Graefe 2002). Achaeta unibulba belongs to a group of species having bottle-shaped glands dorsally and ventrally, the ventral glands being only slightly smaller. Other species of this group are A. eiseni Vejdovský, 1878, A. bulbosa Nielsen \& Christensen, 1961, A. christenseni Prabhoo, 1966, and A. seminalis Kasprzak, 1972 (Vejdovský 1878, Nielsen \& Christensen 1961, Prabhoo 1966, Kasprzak 1972). Principal characters that distinguish the 
new species from this group are the construction of the penial bulb, the absence of accessory penial glands, the arrangement of clitellum glands, and the presence of a large gland at the orifice of the spermathecae. A feature not described in the older literature is the number of preclitellar nephridia. Most species have two pairs from $6 / 7$ to $7 / 8$. Having three pairs, A. unibulba shares this character with A. bifollicula Chalupský, 1992, a species with bottle-shaped glands present only dorsally (Chalupský 1992), and a group of small species without bottle-shaped glands, comprising A. iberica Graefe, 1989, A. pannonica Graefe, 1989, A. etrusca Rota, 1995, and A. petseri Dózsa-Farkas, 1998 (Graefe 1989, Rota 1995, DózsaFarkas et al. 1998).

\section{Occurrence}

Found in a large variety of site conditions including forest, grassland, and arable land, in mineral horizons of mull humus forms as well as in organic horizons of fen peat, $\mathrm{pH}\left(\mathrm{CaCl}_{2}\right)$ 4.2-7.0, moisture conditions (sensu Graefe \& Schmelz 1999) fresh to damp.

Germany: 47 localities including Schleswig-Holstein, Hamburg, Lower Saxony, Bremen, North Rhine-Westphalia, Brandenburg.

Iceland: Vestur.

Denmark: Langstrup Mose, North Zealand, and Ringelmosen, Kalø, Jutland.

Hungary: Bükk Mountains, Omassa, and Zemplén Mountains.

Estonia: Võrtsjärv Limnological Station, Suur Munamägi Hill.

\section{ACKNOWLEDGEMENTS}

We thank Dr. Torben R. Christensen for sampling in the field of Iceland. Thanks are due to the National Scientific Research Foundation (OTKA T 034864) for financing the Hungarian research. Most sites in Germany were investigated in the framework of soil monitoring programmes supported by the environment agencies of Schleswig-Holstein, Hamburg, North Rhine-Westphalia, and the Federal Ministry of Education and Research.

\section{REFERENCES}

Beylich, A. \& Graefe, U. 2002. Annelid coenoses of wetlands representing different decomposer communities. In Wetlands in Central Europe. Soil Organisms, Soil Ecological Processes and Trace Gas Emissions (Broll, G., Merbach, W. \& Pfeiffer, E.-M., eds.), pp. 1-10. Springer, Berlin.

Chalupský, J. 1992. Terrestrial Enchytraeidae (Oligochaeta) and Parergodrilidae (Polychaeta) from Sweden, with description of a new enchytraeid species. Zool. Scr., 21, 133-150.

Dózsa-Farkas, K., Rota, E., Healy, B. \& Timm, T. 1998. Estonian Enchytraeidae (Oligochaeta) 1. Terrestrial Enchytraeidae from the Võrtsjärv Limnological Station and from Puurmani. Proc. Estonian Acad. Sci. Biol. Ecol., 47, 235-246.

Fründ, H.-C. \& Graefe, U. 1994. Die Erfassung von Zersetzerlebensgemeinschaften zur Boden- und Standortcharakterisierung. NNA-Ber., 7, Heft 1, 35-38. 
Graefe, U. 1973. Systematische Untersuchungen an der Gattung Achaeta (Enchytraeidae, Oligochaeta). Diploma thesis, Universität Hamburg.

Graefe, U. 1989. Systematische Untersuchungen an der Gattung Achaeta (Enchytraeidae, Clitellata). 2. Beschreibung von vier neuen Arten. Mitt. hamb. zool. Mus. Inst., 86, 127-131.

Graefe, U. 1993. Die Gliederung von Zersetzergesellschaften für die standortsökologische Ansprache. Mitt. Dtsch. Bodenkdl. Ges., 69, 95-98.

Graefe, U. 1998. Annelidenzönosen nasser Böden und ihre Einordnung in Zersetzergesellschaften. Mitt. Dtsch. Bodenkdl. Ges., 88, 109-112.

Graefe, U. 2002. On the body architecture of the genus Achaeta (Enchytraeidae, Clitellata). In Proc. 4th Int. Symp. Enchytraeidae, Mols Laboratory, Denmark (Christensen, B. \& Standen, V., eds.), p. 106. Nat. Jutl., Occasional Papers, 2 (Newsl. Enchytraeidae, 7).

Graefe, U. \& Schmelz, R. M. 1999. Indicator values, strategy types and life forms of terrestrial Enchytraeidae and other microannelids. In Proc. 3rd Int. Symp. Enchytraeidae, Osnabrück, Germany (Schmelz, R. M. \& Sühlo, K., eds.), pp. 59-67. Universitätsverlag Rasch, Osnabrück (Newsl. Enchytraeidae, 6).

Graefe, U., Elsner, D.-C. \& Necker, U. 1998. Monitoring auf Boden-Dauerbeobachtungsfächen: Bodenzoologische Parameter zur Kennzeichnung des biologischen Bodenzustandes. Mitt. Dtsch. Bodenkdl. Ges., 87, 343-346.

Kasprzak, K. 1972. Achaeta seminalis sp. n., a new species of Enchytraeidae (Oligochaeta) from Poland and notes on other species of the genus Achaeta Vejdovský, 1877. Bull. Acad. Pol. Sci., 20, 187-191.

Mellin, A. 1988. Untersuchungen zur Autökologie und Funktion von Enchytraeiden, Tubificiden und Aeolosomatiden (Annelida, Oligochaeta) im Ökosystem Kalkbuchenwald. Dissertation, Universität Göttingen.

Nielsen, C. O. \& Christensen, B. 1961. The Enchytraeidae. Critical revision and taxonomy of European species. Supplement 1. Nat. Jutl., 10, 1-23.

Prabhoo, N. R. 1966. Studies on Indian Enchytraeidae (Oligochaeta: Annelida) II. Description of two new species. J. Zool. Soc. India, 16, 82-86.

Reisinger, E. 1925. Ein landbewohnender Archiannelide. (Zugleich ein Beitrag zur Systematik der Archianneliden.) Z. Morph. Ökol. Tiere, 3, 197-254.

Rota, E. 1995. Italian Enchytraeidae (Oligochaeta) I. Boll. Zool., 62, 183-231.

Schmelz, R. M., Arslan, N., Bauer, R., Didden, W., Dózsa-Farkas, K., Graefe, U., Panchenko, I., Pokarzhevski, A., Römbke, J., Schlaghamerský, J., Soboczyk, Ł., Somogyi, Z., Standen, V., Thompson, A., Ventiņš, J. \& Timm, T. 2005. Estonian Enchytraeidae (Oligochaeta) 2. Results of a faunistic workshop held in May 2004. Proc. Estonian Acad. Sci. Biol. Ecol., 54, 255-270.

Schulte, W., Fründ, H.-C., Söntgen, M., Graefe, U., Ruszkowski, B., Voggenreiter, V. \& Weritz, N. 1989. Zur Biologie städtischer Böden - Beispielraum Bonn-Bad Godesberg. SchrR. Landschaftspfl. Naturschutz, 33.

Vejdovský, F. 1878. Zur Anatomie und Systematik der Enchytraeiden. Sitzb. K. Böhm. Ges. Wiss. Prag, 1877, 294-304.

\section{Euroopas laialt levinud liik Achaeta unibulba sp. n. (Oligochaeta, Enchytraeidae)}

\section{Ulfert Graefe, Klára Dózsa-Farkas ja Bent Christensen}

Sellel liigil, mida siin on esimest korda vormiliselt kirjeldatud, on erinevalt lähematest sugulastest peniaalsibulikud kõhupoolel osaliselt kokku kasvanud. Teda on varem kohatud Saksamaal, Islandil, Taanis ja Ungaris, nüüd ka Eestis. 